\title{
Glycerol Kinase
}

National Cancer Institute

\section{Source}

National Cancer Institute. Glycerol Kinase. NCI Thesaurus. Code C75500.

Glycerol kinase ( 524 aa, $\sim 57 \mathrm{kDa}$ ) is encoded by the human GK gene. This protein plays a role in glycerol metabolism. 